\title{
Neonatal Hepatitis in Premature Infants Simulating Hereditary Tyrosinosis
}

\author{
J. S. YU, J. A. WALKER-SMITH, „ and E. D. BURNARD \\ From the Department of Child Health, University of Sydney, and Children's Medical Research Foundation, Royal \\ Alexandra Hospital for Children, and the Women's Hospital (Crown Street), Camperdown, N.S.W., Australia
}

\begin{abstract}
Yu, J. S., Walker-Smith, J. A., and Burnard, E. D. (1971). Archives of Disease in Childhood, 46, 306. Neonatal hepatitis in premature infants simulating hereditary tyrosinosis. Three premature infants are reported who developed obstructive jaundice in the first 3 months of life, with a chemical and histological picture consistent with neonatal hepatitis. The disease was complicated by gross generalized aminoaciduria, rickets, and anaemia. Serum tyrosine levels were raised to 0.28-1.64 $\mu \mathrm{mole} / \mathrm{ml}$ in 2 infants, and did not fall in response to ascorbic acid given orally. The infants recovered over the next 3 to 5 months without specific therapy. Many features of the illness in the 3 infants are suggestive of hereditary tyrosinosis, but the transient nature of the illness excluded this diagnosis.

It is suggested that the infants had neonatal hepatitis and that the aminoaciduria and rickets were complications of the hepatitis and the prematurity. The recognition of this syndrome of neonatal hepatitis simulating tyrosinosis is important, if unnecessary and possibly dangerous therapy directed at hereditary tyrosinosis is to be avoided.
\end{abstract}

A high serum tyrosine level may be found in the neonate (Wong, Lambert, and Komrower, 1967; Partington, 1968) in liver disease (Levine and Conn, 1967) and more specifically in hereditary tyrosinosis (Sakai and Kitagawa, 1957; Gentz, Jagenburg, and Zetterström, 1965; Halvorsen et al., 1966). Hereditary tyrosinosis is an inherited metabolic disorder characterized by hepatocellular liver damage which may progress to cirrhosis, hypophosphataemic rickets, renal tubular defects, skin pigmentation, and a moderately raised serum tyrosine. When recognized early, the clinical course can be modified by a restriction of phenylalanine and tyrosine in the diet (Sass-Kortsak et al., 1967; Fairney et al., 1968). The case histories of 3 premature infants with neonatal hepatitis are described in whom complications produced a clinical picture like hereditary tyrosinosis.

\section{Reports}

Case 1. This infant was delivered at 30 weeks' gestation with a birthweight of $1600 \mathrm{~g}$. He developed the respiratory distress syndrome. Jaundice developed

Received 18 December 1970.

*Wellcome Clinical Research Fellow. on the third day and by the fourth day the serum bilirubin reached $14.1 \mathrm{mg} / 100 \mathrm{ml}$, of which $12.9 \mathrm{mg}$ was conjugated. There were no reducing sugars in the urine. A routine urine chromatogram showed a generalized aminoaciduria, with a pattern similar to that seen in prematurity. The jaundice faded slowly but reappeared at 5 weeks when he was noted to be pigmented and unwell. The haemoglobin was $9.6 \mathrm{~g} /$ $100 \mathrm{ml}$ and the serum bilirubin $4 \cdot 1 \mathrm{mg} / 100 \mathrm{ml}$, with $2.4 \mathrm{mg}$ direct reacting. The stools were pale and hepatosplenomegaly was noted. On admission to the Royal Alexandra Hospital for Children, his bilirubin had risen to $8.8 \mathrm{mg} / 100 \mathrm{ml}$ (direct $7.1 \mathrm{mg} / 100 \mathrm{ml}$ ), the serum alkaline phosphatase was $134 \mathrm{~K}$.A. units, and the serum aspartate aminotransferase (SGOT) was 235 Karmen units. Serological tests for syphilis, rubella, and cytomegalovirus were negative. A generalized aminoaciduria persisted and a Millon's test was strongly positive for tyrosine and its metabolites, but a ferric chloride test was negative. Serum tyrosine level was raised $(0 \cdot 28 \mu \mathrm{moles} / \mathrm{ml})$ and this did not fall after oral ascorbic acid $100 \mathrm{mg} 3$ times a day. The serum methionine and serum phenylalanine were normal $(0.044 \mu \mathrm{moles} / \mathrm{ml}$ and $0.118 \mu \mathrm{mole} / \mathrm{ml}$ respectively). $X$-rays of the long bones showed well-developed rachitic changes at 15 weeks, with a serum calcium $7 \cdot 4 \mathrm{mg} / 100 \mathrm{ml}$, serum phosphorus $4.6 \mathrm{mg} / 100 \mathrm{ml}$, and serum alkaline phosphatase 70 K.A. units $/ 100 \mathrm{ml}$. 
Up to this time he had received the routine amounts of vitamin D, 400 IU per day. A liver biopsy showed neonatal hepatitis with giant cells and prominent hepatocellular damage. An operative cholangiogram was normal.

By the time a diagnosis of hereditary tyrosinosis was entertained, he was showing considerable clinical improvement without specific therapy, and his aminoaciduria and raised serum tyrosine level had disappeared (see Table II). This excluded a diagnosis of hereditary tyrosinosis.

He was last seen at 30 months when he was thriving and clinically normal. His liver function tests were normal, his rickets healed, and his urinary amino acid pattern was normal.

Case 2. This child was born at 28 weeks' gestation with a birthweight of $1021 \mathrm{~g}$. He was the second of non-identical twins and at 2 minutes his Apgar rating was $8 / 10$. He had severe recurrent apnoea. At 10 days of age, a routine test on the urine with Millon's solution was strongly positive and his serum tyrosine was raised $\left(1 \cdot 16^{\mu} \mu \mathrm{moles} / \mathrm{ml}\right)$, but serum methionine and serum phenylalanine were normal $(0.012 \mu$ moles/ $\mathrm{ml}$ and $0.097 \mu \mathrm{moles} / \mathrm{ml}$, respectively). The level of serum tyrosine did not fall following the use of ascorbic acid, and reached a peak of $1.64 \mu \mathrm{moles} / \mathrm{ml}$ (see Table II).

At 6 weeks of age he looked slightly jaundiced, pigmented, and his liver was enlarging. The serum tyrosine was $0.54 \mu \mathrm{moles} / \mathrm{ml}$, bilirubin $1.3 \mathrm{mg} / 100 \mathrm{ml}$, SGOT 45 Karmen units, SGPT 40 Karmen units. A month later the bilirubin had risen to $3.5 \mathrm{mg} / 100 \mathrm{ml}$, SGOT 106 Karmen units and SGPT 56 Karmen units. Serological tests and cultures for cytomegalovirus, mycoplasma, toxoplasmosis, and rubella were all negative.

The infant was discharged aged 5 months, still jaundiced and still with hepatomegaly. He was admitted to the Royal Alexandra Hospital for Children for liver biopsy at 6 months. This showed the histological picture of neonatal hepatitis. There was a focal inflammatory reaction with some multinucleated giant cells but little bile stasis. Serum bilirubin $3.3 \mathrm{mg} / 100$ $\mathrm{ml}$ (direct $2 \cdot 2 \mathrm{mg} / 100 \mathrm{ml}$ ), SGOT 360 Karmen units, and SGPT 200 Karmen units. When last seen at $2 \frac{1}{2}$ years a slightly palpable liver was the only anomaly detected.

The other twin had a birthweight of $906 \mathrm{~g}$, and after an episode of the respiratory distress syndrome which was less severe than that of our patient, settled without any complication. She had an early period of mild transient jaundice which settled in 3 days. Her tyrosine was higher than that of her twin at 10 days $(1.64$ $\mu$ moles $/ \mathrm{ml}$ ).

Case 3. This aboriginal infant was seen at 2 days because of jaundice and weighed $1520 \mathrm{~g}$. Over the next 3 months he was nursed in a country hospital because of his small size, persistent jaundice, and recurrent chest infections. At 3 months he was transferred to the Royal Alexandra Hospital for Children. On admission he was jaundiced with a liver palpable
$1 \mathrm{~cm}$ below the costal margin. Serum bilirubin was $4.5 \mathrm{mg} / 100 \mathrm{ml}$ (direct $3.7 \mathrm{mg} / 100 \mathrm{ml}$ ), SGPT 120 Karmen units, $\mathrm{Hb} 8.0 \mathrm{~g} / 100 \mathrm{ml}$, with reticulocytes $5 \%$ and a film suggestive of haemolysis. He had a gross generalized aminoaciduria. The tyrosine spot was noted to be particularly heavy, but no quantitation was performed. There was no glycosuria. $X$-ray of the long bones showed rachitic changes, serum calcium was $7.7 \mathrm{mg} / 100 \mathrm{ml}$, phosphorus $2.9 \mathrm{mg} / 100 \mathrm{ml}$, (phosphorus result repeated), and a serum alkaline phosphatase 83 K.A. units. Serological tests for toxoplasmosis, rubella, syphilis, and cytomegalovirus were negative.

Liver biopsy showed some giant cell transformation and bile retention, but with minimal alteration to liver architecture, i.e. the picture of neonatal hepatitis of mild degree.

He improved slowly on a normal diet with normal vitamin supplements. The jaundice and hepatomegaly resolved over the next 2 months. When seen at 5 years of age there was no clinical or chemical evidence of liver disease. His serum and urinary amino acids were normal and there were no sequelae to his earlier rickets.

\section{Discussion}

Neonatal or giant cell hepatitis is characterized by obstructive jaundice in the first 3 months of life. Its clinical picture, histology, and prognosis have been well described (Craig and Landing, 1952; Brent, 1962; Gellis and Kibrick, 1964; Thaler and Gellis, 1968). The 3 infants described (Table I) fulfil the criteria of the syndrome of neonatal hepatitis.

The presence of hyperpigmentation, aminoaciduria, and high serum tyrosine levels in 2 infants, 1 of whom also had rickets, strongly suggested the possibility of hereditary tyrosinosis. Though a serum tyrosine level was not estimated in the third infant, the similarity of the clinical features, particularly the aminoaciduria with a heavy tyrosine spot, also suggested this diagnosis. However, it was excluded in all 3 infants by the nonprogressive nature of the initial illness and the subsequent recovery of the infants.

Raised serum tyrosine levels are often seen in the neonatal age group, particularly in premature infants (Avery et al., 1967). Unlike our infants, tyrosyluria of the newborn usually responds to large doses of ascorbic acid. The infants described here had a positive Millon-reacting urine initially, but abnormal phenolic acids could not be seen in the urine after admission to the Royal Alexandra Hospital for Children. It seems probable that the raised serum tyrosine levels and the aminoaciduria were related to prematurity (Levine and Conn, 1967). 
TABLE I

Clinical Data and Investigations

\begin{tabular}{|c|c|c|c|}
\hline & Case 1 & Case 2 & Case 3 \\
\hline $\begin{array}{l}\text { Birthweight (g) } \\
\text { Initial onset of jaundice } \\
\text { Exacerbation of jaundice } \\
\text { Duration of jaundice } \\
\text { Maximum bilirubin after } 3 \text { weeks age } \\
\text { Pigmentation } \\
\text { Maximum SGOT (Karmen units } / \mathrm{ml} \text { per min) } \\
\text { SGPT (Karmen units } / \mathrm{ml} \text { per min) } \\
\text { SAP (K.A. units } / 100 \mathrm{ml} \text { ) } \\
\text { Minimum Hb (g/100 ml) } \\
X \text {-ray evidence of rickets } \\
\text { Urinary amino acids } \\
\text { Maximum serum tyrosine ( } \mu \text { mole } / \mathrm{ml} \text { ) }\end{array}$ & $\begin{array}{c}1600 \\
3 \text { days } \\
6 \text { weeks } \\
20 \text { weeks } \\
4 \cdot 4 \mathrm{mg} / 100 \mathrm{ml} \text { (direct } 3 \cdot 5 \text { ) } \\
+ \\
235 \\
198 \\
134 \\
8 \cdot 3 \\
\text { Yes } \\
++ \\
0 \cdot 28\end{array}$ & $\begin{array}{c}1021 \\
3 \text { days } \\
5 \text { weeks } \\
15 \text { weeks } \\
8 \cdot 6 \mathrm{mg} / 100 \mathrm{ml}(\text { direct } 6 \cdot 2) \\
++ \\
360 \\
200 \\
62 \\
8 \cdot 0 \\
\text { No } \\
++ \\
1 \cdot 64\end{array}$ & $\begin{array}{c}1520 \\
2 \text { days } \\
4 \text { weeks } \\
20 \text { weeks } \\
4 \cdot 5 \mathrm{mg} / 100 \mathrm{ml}(\text { direct } 3 \cdot 7) \\
\text { None } \\
67 \\
120 \\
83 \\
8 \cdot 0 \\
\text { Yes } \\
++ \\
\text { Not done }\end{array}$ \\
\hline
\end{tabular}

TABLE II

Plasma Amino Acids ( $\mu$ moles $/ \mathrm{ml}$ )

\begin{tabular}{|c|c|c|c|c|c|c|c|c|}
\hline & \multicolumn{2}{|c|}{10 Days } & \multicolumn{2}{|c|}{17 Days } & \multicolumn{2}{|c|}{36 Days } & \multicolumn{2}{|c|}{51 Days } \\
\hline & Case 2 & Twin Sib & Case 2 & Twin Sib & Case 2 & Twin Sib & Case 2 & Tuin Sib \\
\hline $\begin{array}{l}\text { Taurine } \\
\text { Urea } \\
\text { Threonine } \\
\text { Serine } \\
\text { Glutamine } \\
\text { Proline } \\
\text { Glutamic } \\
\text { Glycine } \\
\text { Alanine } \\
\text { Valine } \\
\text { Methionine } \\
\text { Isoleucine } \\
\text { Leucine } \\
\text { Tyrosine } \\
\text { Phenylalanine } \\
\text { Ornithine } \\
\text { Lysine } \\
\text { Histidine } \\
\text { Arginine } \\
\text { Total amino } \\
\text { acids }\end{array}$ & $\begin{array}{l}0 \cdot 039 \\
0 \cdot 002 \\
0 \cdot 370 \\
0 \cdot 381 \\
0 \cdot 197 \\
0 \cdot 357 \\
0 \cdot 200 \\
0 \cdot 460 \\
0 \cdot 390 \\
0 \cdot 247 \\
0 \cdot 012 \\
0 \cdot 080 \\
0 \cdot 141 \\
1 \cdot 161 \\
0 \cdot 097 \\
0 \cdot 137 \\
0 \cdot 241 \\
0 \cdot 091 \\
0 \cdot 085 \\
4 \cdot 686\end{array}$ & $\begin{array}{l}- \\
0 \cdot 290 \\
0 \cdot 409 \\
0 \cdot 264 \\
0 \cdot 291 \\
0 \cdot 253 \\
0 \cdot 458 \\
0 \cdot 255 \\
0 \cdot 192 \\
0 \cdot 022 \\
0 \cdot 072 \\
0 \cdot 129 \\
0 \cdot 817 \\
0 \cdot 093 \\
0 \cdot 218 \\
0 \cdot 191 \\
0 \cdot 106 \\
0 \cdot 131 \\
4 \cdot 191\end{array}$ & $\begin{array}{l}0 \cdot 040 \\
0 \cdot 008 \\
0 \cdot 595 \\
0 \cdot 427 \\
0 \cdot 395 \\
0 \cdot 397 \\
0 \cdot 101 \\
0 \cdot 381 \\
0 \cdot 325 \\
0 \cdot 310 \\
0 \cdot 027 \\
0 \cdot 090 \\
0 \cdot 186 \\
1 \cdot 642 \\
0 \cdot 136 \\
0 \cdot 265 \\
0 \cdot 349 \\
0 \cdot 133 \\
0 \cdot 146 \\
5 \cdot 953\end{array}$ & $\begin{array}{l}0 \cdot 032 \\
0 \cdot 007 \\
0 \cdot 373 \\
0 \cdot 335 \\
0 \cdot 255 \\
0 \cdot 275 \\
0 \cdot 155 \\
0 \cdot 371 \\
0 \cdot 300 \\
0 \cdot 229 \\
0 \cdot 019 \\
0 \cdot 065 \\
0 \cdot 121 \\
0 \cdot 859 \\
0 \cdot 081 \\
0 \cdot 175 \\
0 \cdot 223 \\
0 \cdot 088 \\
0 \cdot 102 \\
4 \cdot 113\end{array}$ & $\begin{array}{l}0 \cdot 024 \\
0 \cdot 004 \\
0 \cdot 342 \\
0 \cdot 287 \\
0 \cdot 275 \\
0 \cdot 253 \\
0 \cdot 130 \\
0 \cdot 294 \\
0 \cdot 304 \\
0 \cdot 262 \\
0 \cdot 021 \\
0 \cdot 085 \\
0 \cdot 158 \\
1 \cdot 231 \\
0 \cdot 093 \\
0 \cdot 190 \\
0 \cdot 316 \\
0 \cdot 097 \\
0 \cdot 122 \\
4 \cdot 384\end{array}$ & $\begin{array}{l}0 \cdot 022 \\
0 \cdot 005 \\
0 \cdot 345 \\
0 \cdot 329 \\
0 \cdot 186 \\
0 \cdot 411 \\
0 \cdot 175 \\
0 \cdot 335 \\
0 \cdot 295 \\
0 \cdot 289 \\
0 \cdot 017 \\
0 \cdot 098 \\
0 \cdot 187 \\
0 \cdot 524 \\
0 \cdot 117 \\
0 \cdot 189 \\
0 \cdot 294 \\
0 \cdot 083 \\
0 \cdot 097 \\
3 \cdot 993\end{array}$ & $\begin{array}{l}0 \cdot 041 \\
0 \cdot 006 \\
0 \cdot 278 \\
0 \cdot 337 \\
0 \cdot 241 \\
0 \cdot 341 \\
0 \cdot 159 \\
0 \cdot 328 \\
0 \cdot 344 \\
0 \cdot 228 \\
0 \cdot 040 \\
0 \cdot 086 \\
0 \cdot 137 \\
0 \cdot 540 \\
0 \cdot 100 \\
0 \cdot 175 \\
0 \cdot 250 \\
0 \cdot 106 \\
0.090 \\
\\
3 \cdot 821\end{array}$ & $\begin{array}{l}0 \cdot 024 \\
0 \cdot 004 \\
0 \cdot 214 \\
0 \cdot 232 \\
0 \cdot 176 \\
0 \cdot 457 \\
0 \cdot 210 \\
0 \cdot 304 \\
0 \cdot 365 \\
0 \cdot 150 \\
0 \cdot 015 \\
0 \cdot 056 \\
0 \cdot 101 \\
0 \cdot 229 \\
0 \cdot 076 \\
0 \cdot 092 \\
0 \cdot 254 \\
\text { trace } \\
0 \cdot 092 \\
\\
3 \cdot 047\end{array}$ \\
\hline
\end{tabular}

Rickets occurred in two infants despite routine amounts of vitamin D orally (400 IU daily). Norman, Strandvik, and Zetterström (1969) found no clinical or biochemical evidence of rickets in 4 cases of long-standing neonatal hepatitis with marked intrahepatic cholestasis despite gross steatorrhoea, low bile acid secretion and obvious vitamin A malabsorption. However, De Luca (1969) has shown that vitamin D is hydroxylated to its active biological form in the liver. The impairment of this step in the hepatic parenchymal damage found in neonatal hepatitis may be important in the pathogenesis of the rickets.

The 3 infants reported had neonatal hepatitis, but the clinical picture resembled hereditary tyrosinosis in many features and, in the acute phase, could have been misdiagnosed as hereditary tyrosinosis and the infants started on a synthetic diet deficient in tyrosine and phenylalanine. With the increasing use of screening tests, infants with high serum tyrosine levels will be recognized more frequently. Caution must be used in interpreting such results, especially in premature infants. Any treatment involving diets deficient in essential food factors should only be prescribed when skilled dietary advice and continuous laboratory control are available.

The liver biopsies were performed by Dr. W. Grigor, and Dr. B. Turner kindly provided the amino acid studies. 
REFERENCES

Avery, M. E., Clow, C. L., Menkes, J. H., Ramos, A., Scriver, C. R., Stern, L., and Wasserman, B. P. (1967). Transient tyrosinemia of the newborn: dietary and clinical aspects. Pediatrics, $39,378$.

Brent, R. L. (1962). Persisent jaundice in infancy. Fournal of Pediatrics, 61, 111.

Craig, J. M., and Landing, B. H. (1952). Form of hepatitis in the neonatal period simulating biliary atresia. Archives of Pathology, 54, 321.

Deluca, H. F. (1969). Vitamin D. New England Fournal of Medicine, 281, 1103

Fairney, A., Francis, D., Ersser, R. S., Seakins, J. W. T., and Cottom, D. (1968). Diagnosis and treatment of tyrosinosis. Archives of Disease in Childhood, 43, 540.

Gellis, S. S., and Kibrick, S. (1964). Giant cell hepatitis versus bile duct atresia in the neonate. Clinical Pediatrics, 3, 355.

Gentz, J., Jagenburg, R., and Zetterström, R. (1965). Tyrosinemia. An inborn error of tyrosine metabolism with cirrhosis of the liver and multiple renal tubular defects. Fournal of Pediatrics, 66, 670.

Halvorsen, S., Pande, H., Løken, A. C., and Gjessing, L. R. (1966). Tyrosinosis. A study of 6 cases. Archives of Disease in Childhood, 41, 238.

Levine, R. J., and Conn, H. O. (1967). Tyrosine metabolism in patients with liver disease. Fournal of Clinical Investigation, 46, 2012.

Norman, A., Strandvik, B., and Zetterström, R. (1969). Bile acid excretion and malabsorption in intrahepatic cholestasis of infancy ('neonatal hepatitis'). Acta Paediatrica, 58, 59.

Partington, M. W. (1968). Neonatal tyrosinaemia. Biologia Neonatorum, 12, 316.

Sakai, K., and Kitagawa, T. (1957). An atypical case of tyrosinosis. fikeikai Medical fournal, 4, 1.

Sass-Kortsak, A., Ficici, S., Paunier, L., Kooh, S. W., Fraser, D., and Jackson, S. H. (1967). Observations on treatment of patients with tyrosyluria. Canadian Medical Association fournal, 97, 1089.

Thaler, M. M., and Gellis, S. S. (1968). Studies in neonatal hepatitis and biliary atresia. American fournal of Diseases of Children, 116, 257

Wong, P. W. K., Lambert, A. M., and Komrower, G. M. (1967). Tyrosinaemia and tyrosyluria in infancy. Developmental Medicine and Child Neurology, 9, 551.

Correspondence to J. S. Yu, Department of Child Health, Royal Alexandra Hospital for Children, Camperdown, N.S.W., Australia, 2050. 